\title{
Correction to: LncRNA SNHG1 contributes to sorafenib resistance by activating the Akt pathway and is positively regulated by miR-21 in hepatocellular carcinoma cells
}

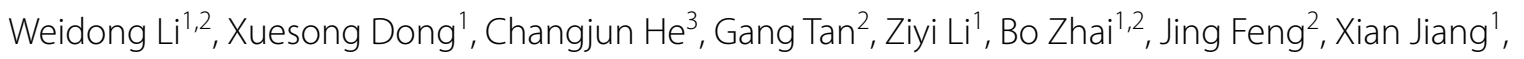
Chang Liu ${ }^{2}$, Hongchi Jiang ${ }^{1}$ and Xueying Sun ${ }^{1 *}$

Correction to: J Exp Clin Cancer Res 38, 183 (2019)

https://doi.org/10.1186/s13046-019-1177-0

Following publication of the original article [1], the authors identified some minor errors in Figs. 3 and 4, specifically:

- In Fig. 3a, the cytometrical dot plots originally contained errors

- In Fig. 4f, an incorrect image was originally used for the anti-SNHG1-treated tumor sections $\left(1^{\text {st }}\right.$ row, $3^{\text {rd }}$ column)

The authors provided the Journal with the original data. The corrected figures are given here. The corrections do not have any effect on the final conclusions of the paper. The original article has been corrected.

\section{Author details}

'The Hepatosplenic Surgery Center, The First Affiliated Hospital of Harbin Medical University, Harbin 150001, China. ${ }^{2}$ Department of General Surgery, The Fourth Affiliated Hospital of Harbin Medical University, Harbin 150001, China. ${ }^{3}$ Department of Surgery, The Third Affiliated Hospital of Harbin Medical University, Harbin, China.

The original article can be found online at https://doi.org/10.1186/s13046019-1177-0.

*Correspondence: sunxueying@hrbmu.edu.cn; k.sun@auckland.ac.nz

${ }^{1}$ The Hepatosplenic Surgery Center, The First Affiliated Hospital of Harbin Medical University, Harbin 150001, China

Full list of author information is available at the end of the article
Published online: 01 December 2021

\section{Reference}

1. Li W, Dong X, He C, et al. LncRNA SNHG1 contributes to sorafenib resistance by activating the Akt pathway and is positively regulated by miR-21 in hepatocellular carcinoma cells. J Exp Clin Cancer Res. 2019;38:183. https://doi.org/10.1186/s13046-019-1177-0.

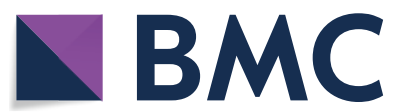

(c) The Author(s) 2021. Open Access This article is licensed under a Creative Commons Attribution 4.0 International License, which permits use, sharing, adaptation, distribution and reproduction in any medium or format, as long as you give appropriate credit to the original author(s) and the source, provide a link to the Creative Commons licence, and indicate if changes were made. The images or other third party material in this article are included in the article's Creative Commons licence, unless indicated otherwise in a credit line to the material. If material is not included in the article's Creative Commons licence and your intended use is not permitted by statutory regulation or exceeds the permitted use, you will need to obtain permission directly from the copyright holder. To view a copy of this licence, visit http://creativecommons.org/licenses/by/4.0/. The Creative Commons Public Domain Dedication waiver (http://creativeco mmons.org/publicdomain/zero/1.0/) applies to the data made available in this article, unless otherwise stated in a credit line to the data. 
A
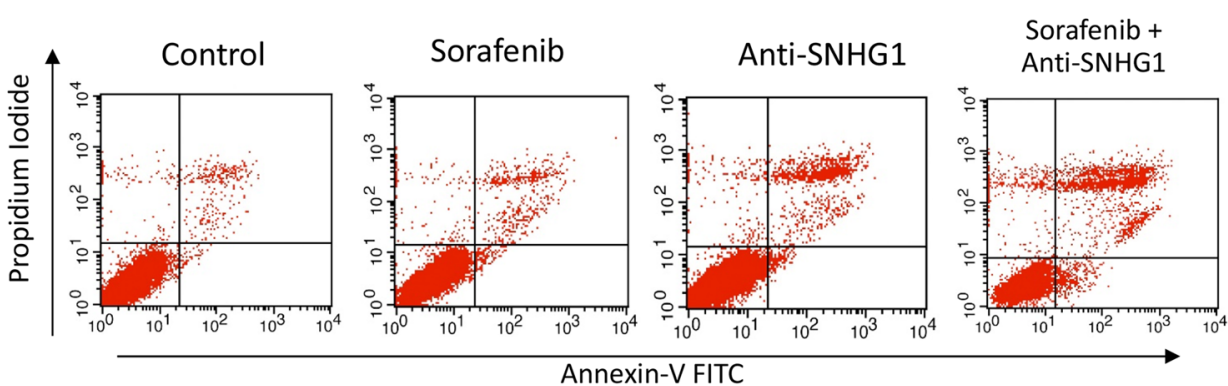

B
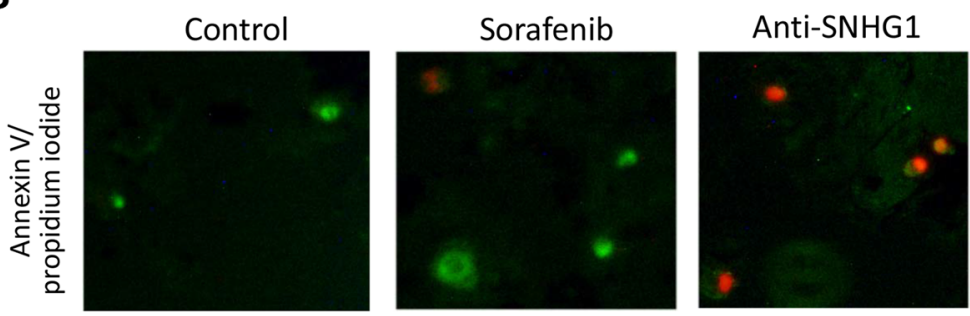

Sorafenib +
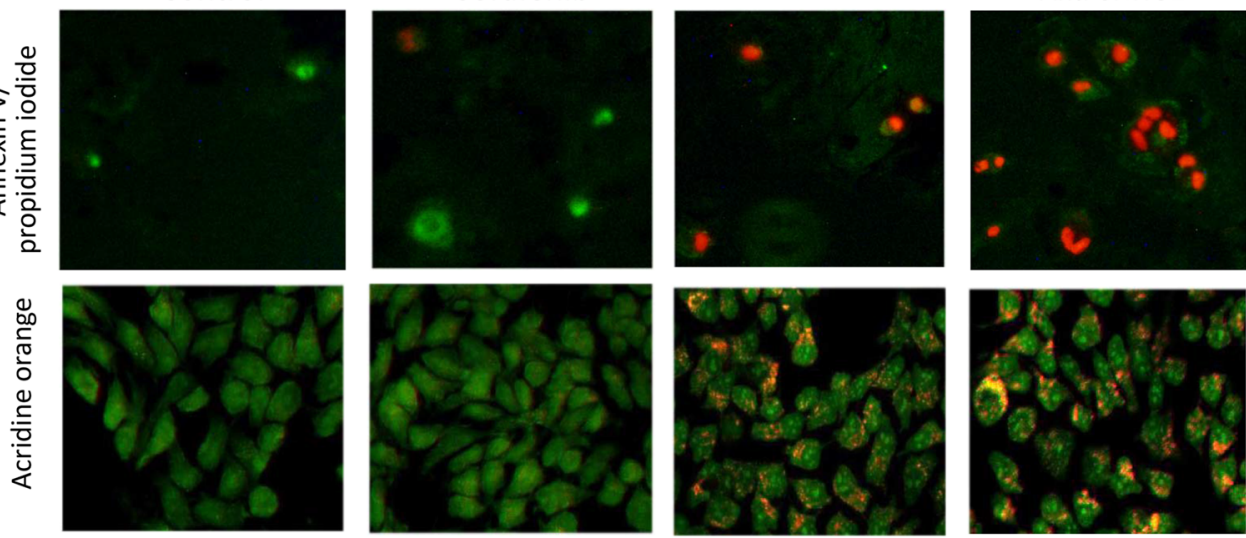

C

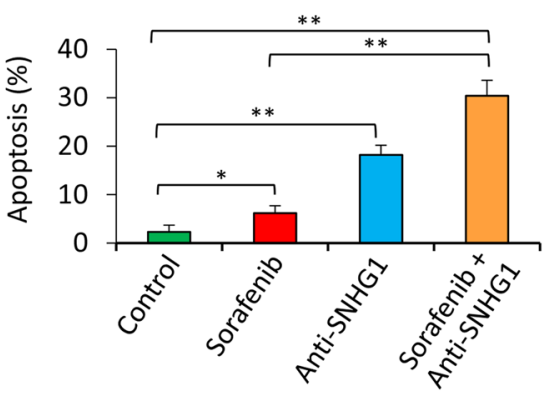

D

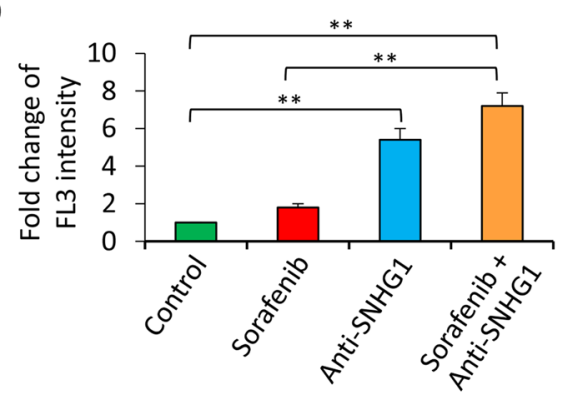

E

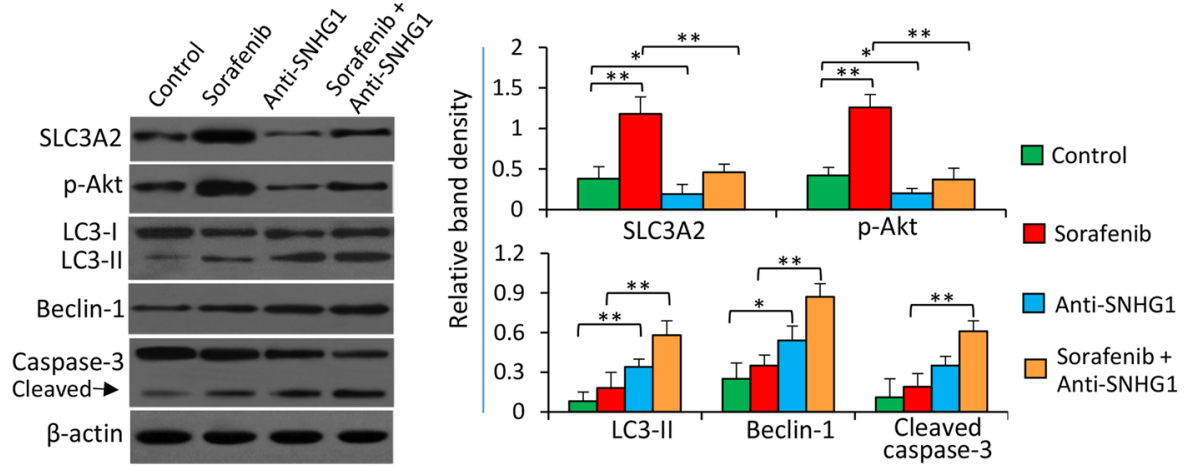

Fig. 3 Depletion of SNHG1 enhances the effects of sorafenib in promoting apoptosis and autophagy of sorafenib-resistant cells. Huh7-SR cells either untreated (control) or transfected with SNHG1 Smart Silencer (anti-SNHG1) were incubated for $48 \mathrm{~h}$ in the absence or presence of sorafenib $(5 \mu \mathrm{M})$. a Representative dot plots were from the above cytometrically analyzed cells. $\mathbf{b}$ Representative images were taken from the above cells stained by Annexin V/propidium iodide or acridine orange (magnification $\times 200$ ). c Cell apoptosis (\%) was measured by cytometry. $\mathbf{d}$ The fold change of acridine orange fluorescence intensity (FL3) versus the untreated controls, which was defined as 1, was calculated. e Cells were subjected to Western blot analysis. The density of each band was normalized to $\beta$-actin. "**" $(P<0.05)$ and "**" $(P<0.001)$ indicate a significant difference 


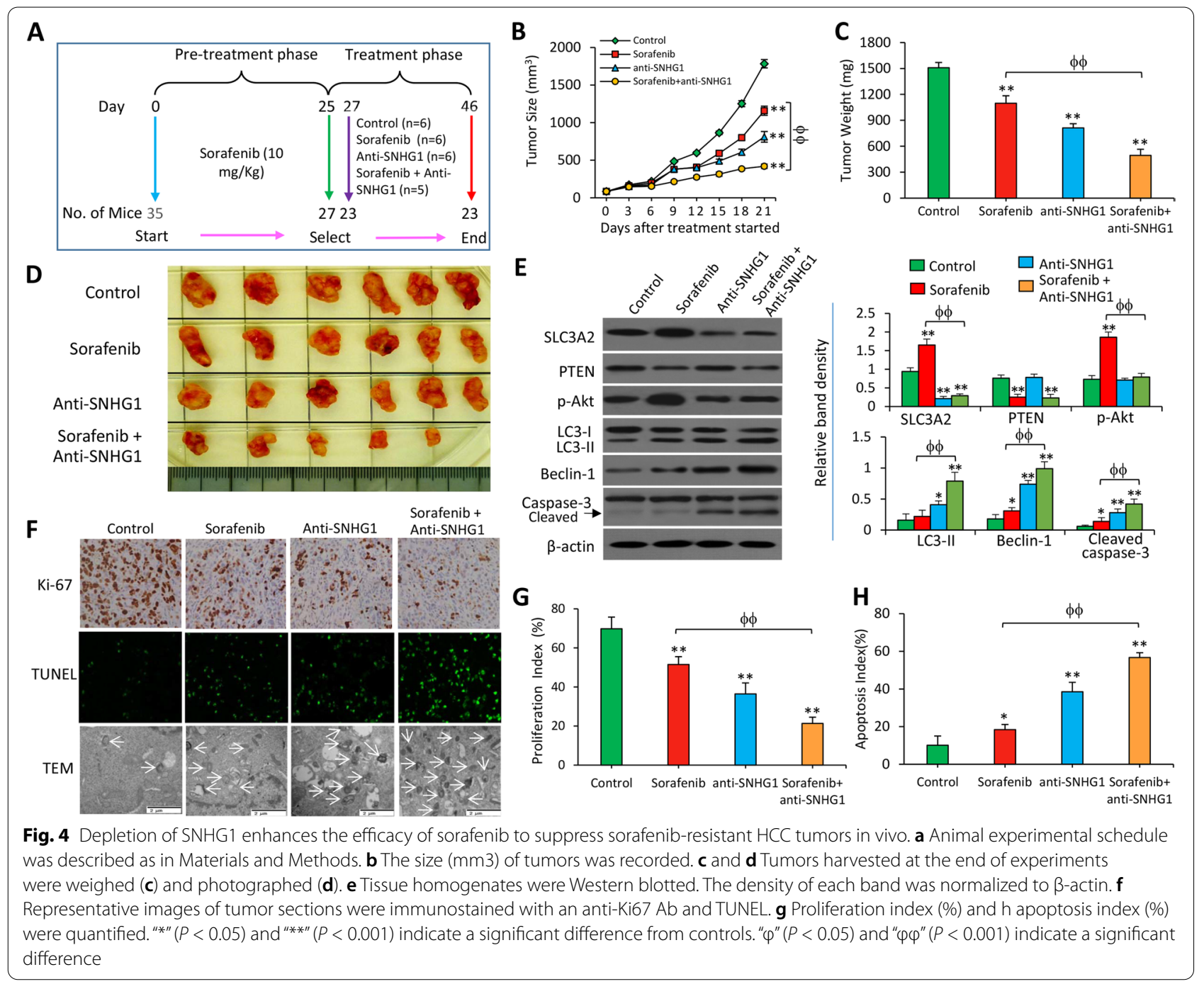

